\title{
Definitely Disagree
}

National Cancer Institute

\section{Source}

National Cancer Institute. Definitely Disagree. NCI Thesaurus. Code C103802.

An unequivocal feeling of opposition. 